\title{
Modeling Coastal Marsh Restoration Benefits in the Northern Gulf of Mexico
}

\author{
Gail F. Fricano ${ }^{1} \cdot$ Matthew S. Baumann ${ }^{1} \cdot$ Katie Fedeli $^{1} \cdot$ Claire E. Schlemme $^{1} \cdot$ Melissa Vernon Carle $^{2} \cdot$ Mel Landry $^{3}$
}

Received: 25 May 2018 / Revised: 6 January 2020 / Accepted: 23 January 2020 / Published online: 4 February 2020

(C) The Author(s) 2020

\begin{abstract}
Extensive salt marsh restoration is expected in the northern Gulf of Mexico over the next several decades, funded in part by settlements from the 2010 Deepwater Horizon oil spill. Understanding the ecological benefits of restored marshes over time is integral to setting appropriate restoration targets and performance criteria and in determining the restoration area needed to achieve desired restoration goals and offset quantified natural resource injuries. We present a method for quantifying anticipated ecological benefits associated with marsh restoration projects, particularly marsh creation or enhancement through the placement of dredged material, in the northern Gulf of Mexico. Using salt marsh vegetation (percent cover, aboveground biomass, and belowground biomass) and indicator faunal species (periwinkle snails and amphipods) as representative marsh community components, we used resource equivalency analysis (REA) to model projected ecological benefits over time and quantified total net project benefits for a hypothetical marsh creation project in Barataria Bay, Louisiana. Sensitivity analysis of the resulting model suggests that the recovery trajectories for each marsh component were the most important drivers of modeled restoration benefits and that model uncertainty was greatest for marsh fauna, which has limited data availability compared to marsh vegetation and high natural variability. Longer-term monitoring at restored restoration sites and/or targeted monitoring of older restoration projects would reduce variability in the recovery trajectories for the marsh community components examined in this case study and improve the reliability of the REA model for projecting benefits associated with salt marsh restoration.
\end{abstract}

Keywords Salt marsh $\cdot$ Ecological restoration $\cdot$ Resource equivalency analysis $\cdot$ Natural resource damage assessment

\section{Introduction}

The quantification of ecological benefits of wetland restoration projects is frequently applied in the context of natural

Communicated by John C. Callaway

Electronic supplementary material The online version of this article (https://doi.org/10.1007/s12237-020-00706-3) contains supplementary material, which is available to authorized users.

Gail F. Fricano

gfricano@indecon.com

Matthew S. Baumann

mbaumann11985@gmail.com

Katie Fedeli

katieafedeli@gmail.com

Claire E. Schlemme

claire.schlemme@gmail.com

Melissa Vernon Carle

melissa.carle@noaa.gov resource damage assessment (NRDA) restoration scaling using resource equivalency analysis (REA) or habitat equivalency analysis (HEA). Restoration scaling is a process used to determine the type and quantity of restoration needed to
Mel Landry

mel.landry@noaa.gov

Industrial Economics, Inc., 2067 Massachusetts Avenue, Cambridge, MA 02140, USA

2 NOAA Restoration Center, SSMC3, Room 14720, 1315 East-West Highway, Silver Spring, MD 20910, USA

3 NOAA Restoration Center, 5304 Flanders Drive, Suite B, Baton Rouge, LA 70808, USA 
compensate the public for ecological services or natural resources lost as a result of an oil spill or hazardous waste release (NOAA 1996; U.S. DOI 2008). Although REAs and HEAs are a frequent component of NRDA cases in the U.S. and have supported a multitude of government claims, few peer-reviewed papers present detailed applications (but see Peterson and Kneib 2003 for marine examples and Dunford et al. 2004 for a wetland example). Several publicly available reports and conference proceedings provide some detail on model inputs and methods for wetland HEAs or REAs, but data-derived justifications for model inputs and model assumptions are not well documented, particularly for the quantification of anticipated restoration benefits (Cosco Busan Oil Spill Trustees 2012; Desvousges et al. 2018; Gala et al. 2008; Hampton and Zafonte 2002; Michel et al. 2002; Stratus Consulting and Toxicological, and Environmental Associates, Inc. 2006).

The 2010 Deepwater Horizon (DWH) oil spill was the largest marine oil spill in U.S. waters and one of the largest worldwide (DWH NRDA Trustees 2016). The spill resulted in oiling of over $1105 \mathrm{~km}$ of vegetated shoreline, primarily Spartina alterniflora-dominated salt marshes, from Florida through Texas (DWH NRDA Trustees 2016). Adverse effects were documented for all major community components of the marsh ecosystem, including vegetation, periwinkle snails (Littoraria irrorata), amphipods (order Amphipoda), and nekton, among others (Baker et al. 2017; DWH NRDA Trustees 2016; Hester et al. 2016; Lin and Mendelssohn 2012; Zengel et al. 2014, 2015). As a result of the settlement of liability for the spill, billions of dollars will be available for coastal and nearshore habitat restoration, including wetland restoration (U.S. DOJ 2015; U.S. Treasury 2015). The significant amount of anticipated wetland restoration underscores the importance of understanding the ecological benefits that wetland restoration projects in this region provide over time for resources and services injured by the spill.

Here, we present a REA-based method for quantifying anticipated ecological benefits associated with marsh restoration projects in the northern Gulf of Mexico. This REA framework synthesizes the best available information for model parameters, including recovery trajectories for different components of the restored marsh ecosystem, combined with assumptions developed based on best professional judgment where relevant empirical data are currently lacking. To demonstrate utility of the REA model, we present a case study focused on a hypothetical salt marsh creation project in Barataria Bay, Louisiana, where most of the documented Deepwater Horizon marsh injury occurred (DWH NRDA Trustees 2016) (Fig. 1). We also describe how the model can be adapted for marshes elsewhere in the northern Gulf of Mexico and beyond. Where possible, we present suites of input values that users can select from based on project location (Louisiana basin), marsh type (salt, brackish, intermediate, fresh), and restoration technique (marsh creation, hydrologic restoration, shoreline protection). The approach presented here can assist restoration managers in synthesizing existing information to make informed assumptions about the ecological benefits associated with a specific wetland restoration project. This can help set realistic restoration targets and assist with evaluating restoration project outcomes relative to modeled expectations. We present detailed datadriven inputs that should benefit future NRDA restoration scaling efforts and identify data gaps and uncertainties that can inform future research to strengthen model reliability.

\section{Methods}

\section{Description of Model}

The conceptual basis and mathematical framework for HEA and REA are well documented, though REA is less frequently described (Desvousges et al. 2018; Hampton and Zafonte 2002; NOAA 2006; Peterson and Kneib 2003). For NRDAs, REAs are customized on a case-specific basis to address project characteristics, while maintaining the basic framework that defines a REA. The model described here reflects the conceptualization of a hypothetical marsh restoration project in Louisiana and uses project-specific inputs, such as marsh loss rates, derived based on available data.

Typically, a REA model comprises two components: one that quantifies natural resource injuries (losses), and the other that quantifies the benefits of a restoration project (gains) (European Commission 2007; NOAA 2006). These two components together allow for a determination of the amount of restoration needed to compensate for the injury (restoration scaling). Because the focus of this paper is the determination of restoration benefits, the model presented here is specific to the restoration component of the REA framework.

We quantified the benefits associated with a hypothetical marsh creation project using a set of metrics that characterize the condition of marsh vegetation and selected faunal communities and serve as indicators of marsh health (DWH NRDA Trustees 2016). These metrics include total live vegetation cover, aboveground plant biomass (live standing crop dry weight), belowground biomass (dry weight), biomass of periwinkle snails (L. irrorata; wet weight), and abundance of amphipods (order Amphipoda). The vegetation metrics are intended to reflect the vascular plant primary production of the marsh as well as the structural habitat that the vegetation community provides for faunal resources. Periwinkle snails and amphipods are lower-trophic-level consumers in the marsh food web and are important indicators of broader ecological marsh function. Periwinkles are important grazers in the marsh, facilitating decomposition and carbon and nutrient cycling (Kemp et al. 1990; Silliman and Zieman 2001). 


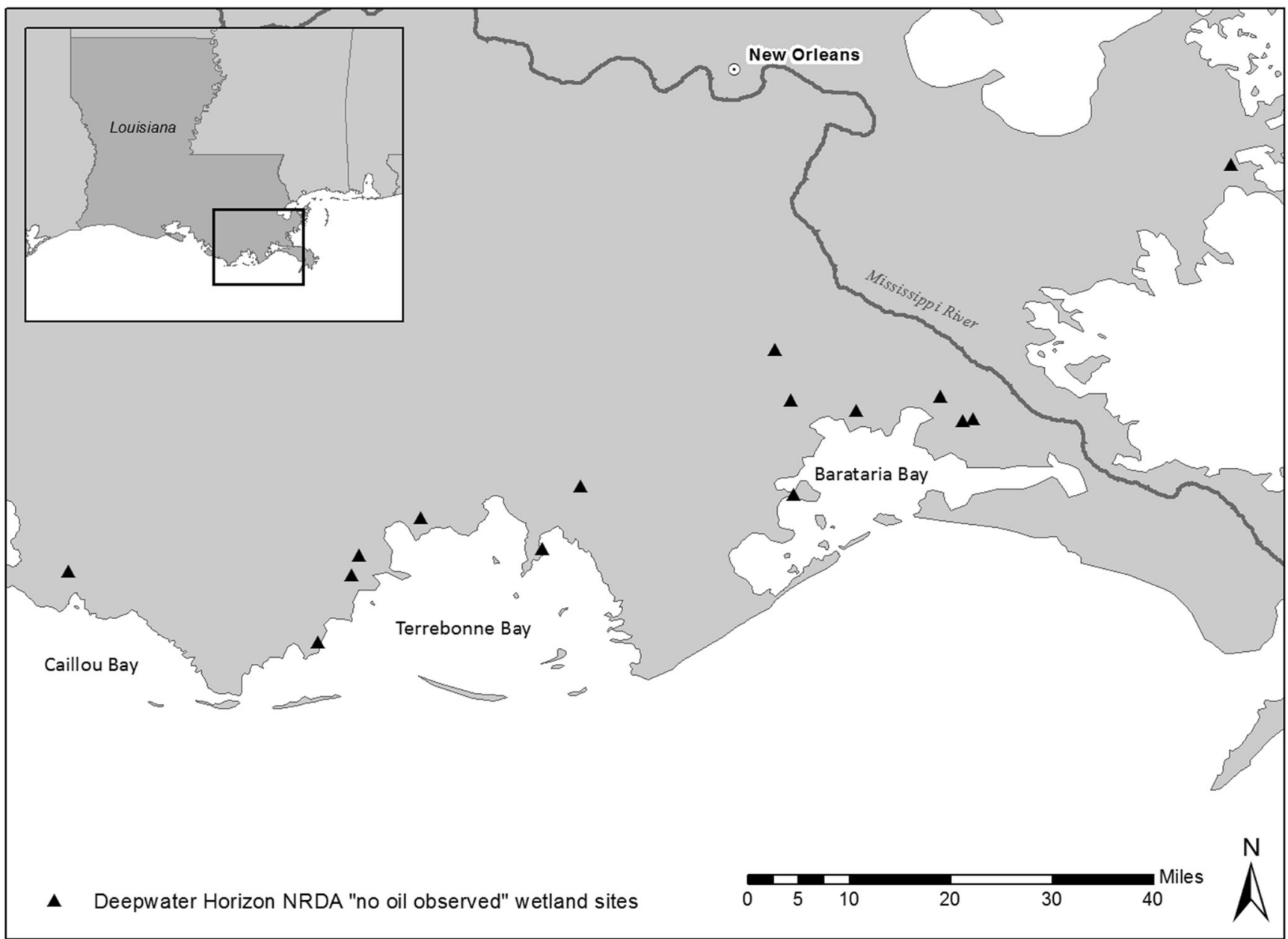

Fig. 1 Sites used to derive vegetation reference values. These sites were sampled during the Deepwater Horizon NRDA by Hester et al. (2016) and had no visible oiling (NOAA DIVER)

Amphipods provide a key food source for marsh-dependent nekton such as white shrimp (Litopenaeus setiferus), brown shrimp (Farfantepenaeus aztecus), killifish (Fundulus spp.), and flounder (Paralichthys lethostigma) (Akin and Winemiller 2008; Burke 1995; McTigue and Zimmerman 1998).

For each metric, the net benefits of a marsh restoration project are calculated as the difference between the ecological benefits provided by the restoration project (Future with Project, FWP) and the ecological benefits provided by the same area in the absence of the project (Future without Project, FWOP). Net benefits are expressed on a per $\mathrm{m}^{2}$ basis (e.g., biomass per $\mathrm{m}^{2}$ ) and are calculated for each year over the life of the project. The annual net benefits are then discounted to present value years and summed to calculate total present value net benefits per $\mathrm{m}^{2}$ (NOAA 1999). The model assumes that net benefits can result from increasing the proportion of the site that is covered by marsh or from reducing the baseline rate of incremental marsh loss within the project footprint. A series of schematic plan views of the FWOP marsh and FWP marsh at several time periods for a hypothetical marsh creation project illustrate the concepts of FWP, FWOP, area of marsh creation, project area, percent marsh (FWOP), annual percent loss of the marsh platform (FWOP), and FWP marsh platform loss reduction (Fig. 2).

The quantity of benefits $\left(Q_{I, t}\right)$ expected in the FWOP scenario $(I)$ for a particular year $(t)$ is calculated for each specific vegetation or fauna metric (e.g., biomass of periwinkles per unit area):

$Q_{I, t}=F^{*} \sigma^{*} L_{I, t}$

The FWOP metric-based function $(F)$ represents the benefits specific to the vegetation or fauna metric of interest provided by the reference marsh per unit area of marsh. Sigma $(\sigma)$ represents the percent of the project site comprised of marsh in the absence of restoration. Areas not consisting of marsh are assumed to provide no benefits with respect to the metric of interest, though we acknowledge that open water and benthic habitats provide ecological value more broadly. This 
Fig. 2 Schematic plan views of a hypothetical marsh creation project illustrating the concepts of FWP, FWOP, marsh creation, project area, percent marsh (FWOP), annual percent loss of marsh platform (FWOP), and FWP marsh platform loss reduction. Year $_{0}$ is prior to project implementation. Year $_{1}$ is the first year following marsh creation. Year $_{\text {end }}$ represents the end of the project life. Project area is the area of dredged material placement for a marsh creation project
Future Without Project Year $_{0}$

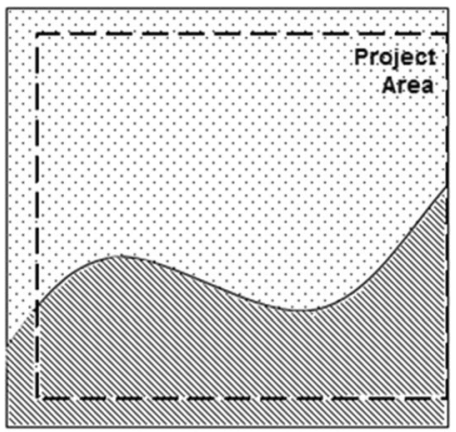

Future with Project Year $_{1}$

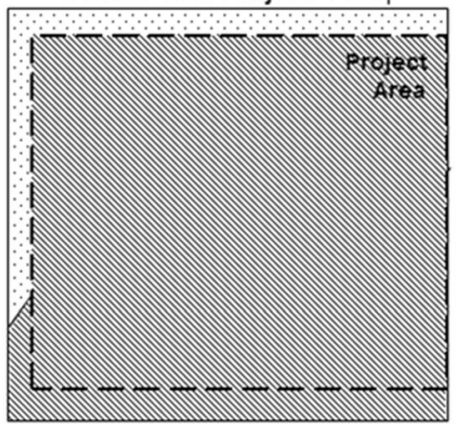

Future Without Project Year $_{\text {end }}$

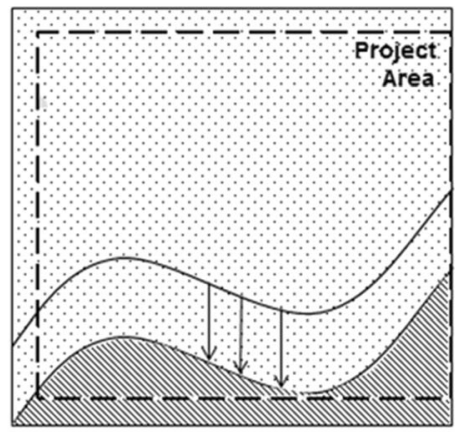

Future with Project Year $_{\text {end }}$

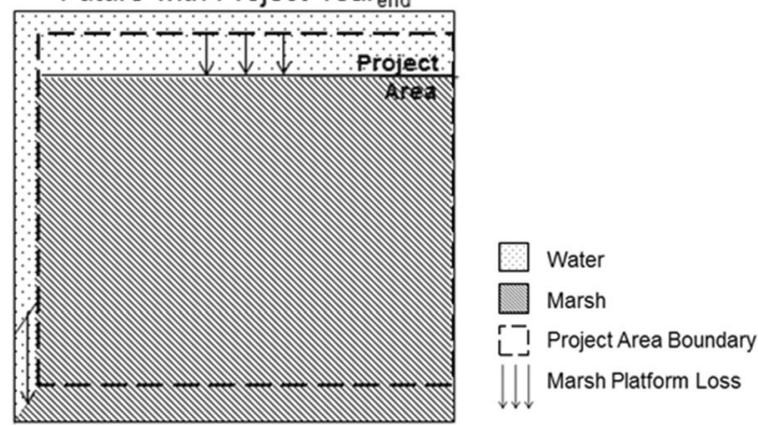

assumption is appropriate for marsh vegetation and periwinkle snails, which are entirely dependent on the marsh platform. The assumption may be less appropriate for amphipods, which also inhabit shallow open water areas adjacent to marshes, and may result in an overestimation of amphipod net project benefits. $L_{I, t}$ is the percent of the initial marsh that remains, accounting for natural (FWOP) loss of the marsh platform at time $t$ :

$L_{I, t}=L_{I, t_{0}}-\varepsilon_{\mathrm{I}} *\left(t-t_{0}\right)$

Epsilon $\left(\varepsilon_{I}\right)$ is a constant FWOP marsh platform loss rate in percent per year. Marsh losses are projected to occur over time due to factors such as platform subsidence, marsh edge and surface erosion, and eustatic sea-level rise exceeding marsh accretion rates. $L_{I, t_{0}}$ is the percent of the initial marsh that remains in the first year of the project (assumed to be 100\%). Using the concepts presented in Fig. 2, the FWOP marsh platform loss rate is defined as:

Annual marsh platform loss rate

$$
=\frac{\text { Marsh Area Year } 1-\text { Marsh Area Year }_{\text {end }}}{\text { Marsh area Year } 1 *\left(\text { Year }_{\text {end }}-\text { Year }_{1}\right)}
$$

In the FWP scenario $(R)$, we assume the entire project area will consist of marsh, and benefits in a particular year $\left(Q_{R, t}\right)$ are calculated as the product of a measure of benefits provided at time $t\left(\varphi_{t}\right)$, and the area of the marsh remaining at time $t\left(L_{R, t}\right)$ :
$Q_{R, t}=\varphi_{t} * L_{R, t}$

FWP ecological metric-based function $\left(\varphi_{t}\right)$ represents the benefits specific to the vegetation or fauna metric of interest that are provided by the restoration site per unit area of marsh (Eq. 1).

The percent of the initial restored marsh that remains is calculated as:

$L_{R, t}=L_{R, t_{0}}-\varepsilon_{R} *\left(t-t_{0}\right)$

$L_{R, t_{0}}$ is the percent of the initial restored marsh that remains in the first year that project construction is completed (assumed to be $100 \%$ ), and $\varepsilon_{R}$ is the FWP annual marsh platform loss rate, expressed as a fixed percentage per year and calculated as:

$\varepsilon_{R}=\eta^{*} \varepsilon_{I}$

where $\eta$ is the FWP annual percent reduction in marsh platform loss (compared to the FWOP annual marsh platform loss rate) due to implementation of the restoration project (FWP marsh platform loss reduction).

The net benefit of the project $\left(Q_{N}\right)$ is the sum, for each year, of the present value difference between the FWP and FWOP scenarios:

$Q_{N}=\sum_{t=t_{0}}^{H}\left(Q_{R, t}-Q_{I, t}\right) * \rho_{t}$ 
where $t_{0}$ is the year that construction of the restoration project is completed, $H$ is the year in which the project's benefits end, and $\rho_{t}$ is the discount factor. The discount factor $\left(\rho_{t}\right)$ is calculated as:

$\rho_{t}=(1+d)^{-(t-P)}$

where $d$ is the annual discount rate and $P$ is the present year (i.e., the year in which discounted benefits are expressed, for which we use 2016). A discount rate of $3 \%$ is recommended by NOAA for HEA and REA applications (NOAA 1999).

\section{Case Study: Marsh Creation in Barataria Bay, Louisiana}

Over $1000 \mathrm{~km}$ of marsh shoreline was oiled in Louisiana as a result of the 2010 Deepwater Horizon oil spill, with much of the heaviest oiling occurring in Barataria Bay (Nixon et al. 2016). As a result, over $\$ 4$ billion has been specifically allocated to the restoration of wetlands, coastal, and nearshore habitat in Louisiana under the Deepwater Horizon settlement for natural resource damages. Baseline marsh loss rates in Barataria Bay are high due in large part to levees along the Mississippi River that limit input of river water and sediment to the deltaic marshes. Other causes of high marsh loss rates in coastal Louisiana include erosion of the marsh edge, subsidence, eustatic sea-level rise, stochastic storm events, and the dredging of canals (Barras et al. 2008; Barras 2009; Boesch et al. 1994; Couvillion et al. 2011; Dahl and Stedman 2013; Day Jr. et al. 2000, 2007; Kesel 1988; Turner 1997). Marsh creation or enhancement through the placement of dredged material (collectively referred to as marsh creation in this paper) is a technique commonly used to combat wetland loss in the Mississippi River delta region (Coastal Protection and Restoration Authority of Louisiana 2017; LCWCRTF 2014) and is a component of the strategic restoration plan for Barataria Bay developed by the Deepwater Horizon Louisiana Trustee Implementation Group (DWH NRDA Trustees 2018). In Louisiana, sediments hydraulically dredged and pumped from the Mississippi River or transported from nearshore borrow pits are used to create marsh in existing shallow unvegetated open water areas or to restore or enhance existing, degraded marsh platform through application of dredged sediment to fill fragmented areas and increase the elevation of the existing marsh platform through a technique known as "thin layer placement" (Ford et al. 1999; La Peyre et al. 2009; Stagg and Mendelssohn 2010; Turner and Streever 2002). The high likelihood of future marsh creation in Barataria Bay, Louisiana makes this a particularly relevant case study to demonstrate application of our REA model.
Model Parameterization for Barataria Bay, Louisiana

Table 1 summarizes the input values used to parameterize the REA model for a hypothetical marsh creation project in Barataria Bay, Louisiana.

\section{Project Life}

Project life is the maximum duration over which the project is reliably expected to provide benefits and is typically a function of the type of project, the duration of maintenance funding, and the potential for human or natural disturbances that reduce project performance. Relative sea-level rise is accounted for in the annual percent loss of marsh platform parameter described below and is therefore not a consideration for estimating project life. For the hypothetical marsh creation project in Barataria Bay, we assumed a project life of 20 years, consistent with the project life used by the Coastal Wetlands Planning, Protection, and Restoration Act (CWPPRA) program's Wetland Value Assessment (WVA) analyses (LCWCRTF 2014).

\section{Reference Marsh Conditions}

For purposes of this REA model, a reference marsh is defined as a marsh that has not been subject to prior restoration and has not experienced recent physical disturbance or significant contamination. To the extent possible, the reference marsh conditions should approximate the range of conditions expected for the restored marsh in terms of hydrology, salinity, climate, plant community, and geomorphic setting (Brinson and Rheinhardt 1996; Steyer et al. 2006; White and Walker 1997). While all of the literature data used to derive reference values for this model were from sites designated as "reference" in their respective studies, the specific criteria used to select a reference marsh may differ between studies.

Reference values for vegetation parameters for the Barataria Bay model were derived from field data collected as part of the Deepwater Horizon oil spill NRDA (Hester et al. 2016). These reference sites were marshes with no visible oiling randomly selected along the Louisiana coast in the general vicinity of the area of oil impact (Figure 1). One hundred and forty-eight observations of aboveground biomass and vegetation cover were collected across the 2010 to 2013 fall sampling seasons (15 sites with up to three plots each across four seasons; Table 1) and 146 observations of belowground biomass were collected over the same sampling period.

Reference densities for periwinkles and amphipods in coastal salt marshes were derived from a literature review summarized by Baumann et al. (2018). The mean density of periwinkles in Louisiana salt marshes was based on data reported in nine studies. An age-class survivorship curve based on natural mortality (Hoenig 1983) derived from Powers and 
Table 1 Input values for parameterization of the model for created salt marsh in Barataria Bay, Louisiana

\begin{tabular}{|c|c|c|}
\hline Input type & Input value & Source \\
\hline Project life ${ }^{\mathrm{f}}$ & 20 years & LCWCRTF 2014 \\
\hline \multicolumn{3}{|l|}{ Reference value for metric of interest } \\
\hline Aboveground biomass (live) & $907 \pm 33$ g dry weight $\mathrm{m}^{-2}$ & Hester et al. $2016^{\mathrm{a}}$ \\
\hline Belowground biomass (total) & $15,120 \pm 470$ g dry weight $\mathrm{m}^{-3}$ & Hester et al. $2016^{\mathrm{a}}$ \\
\hline Total live vegetation cover & $51 \pm 2.0 \%$ & Hester et al. $2016^{\mathrm{a}}$ \\
\hline Periwinkle density & 41 sub-adults and adults $\mathrm{m}^{-2}$ & Baumann et al. 2018 \\
\hline Amphipod density & 1294 individuals $\mathrm{m}^{-2}$ & Baumann et al. 2018 \\
\hline \multicolumn{3}{|l|}{ Recovery trajectory of restored marsh for metric of interest ${ }^{\mathrm{b}}$} \\
\hline Aboveground biomass & Recovery to reference biomass by year 1 & Ebbets et al. 2019 \\
\hline Belowground biomass & Recovery to reference biomass by year 18 & Ebbets et al. 2019 \\
\hline Total live cover & $\begin{array}{l}\text { Recovery to reference biomass by year } 5 \text {, then } \\
\text { slight decline }\end{array}$ & Ebbets et al. 2019 \\
\hline Periwinkles & Recovery to reference density by year $4^{\mathrm{c}}$ & Baumann et al. 2018 \\
\hline Amphipods & Uniform function of $48 \%$ throughout project life & Baumann et al. 2018 \\
\hline Construction completion date & 2024 & CWPPRA $^{\mathrm{d}}$ \\
\hline Annual percent loss of marsh platform (FWOP) & $-1.51 \%$ & $\begin{array}{l}\text { Couvillion et al. } \\
\text { unpublished data }\end{array}$ \\
\hline $\begin{array}{l}\text { FWP marsh platform loss reduction (relative to FWOP marsh } \\
\text { platform loss rate) }\end{array}$ & $50 \%$ & LCWCRTF 2014 \\
\hline Percent marsh (FWOP) & $20 \%$ & CWPPRA $^{\mathrm{e}}$ \\
\hline Discount rate ${ }^{\mathrm{f}}$ & $3 \%$ per year & NOAA 1999 \\
\hline Current year (for discounting purposes) ${ }^{\mathrm{f}}$ & 2016 & \\
\hline
\end{tabular}

${ }^{a}$ Available though the NOAA DIVER database. https://dwhdiver.orr.noaa.gov/

${ }^{\mathrm{b}}$ Used in derivation of function

${ }^{\mathrm{c}}$ Paired with information on survivorship and biomass per age class to calculate annual biomass gained

${ }^{\mathrm{d}}$ CWPPRA web site. www.lacoast.gov

${ }^{\mathrm{e}}$ CWPPRA WVA worksheets

${ }^{\mathrm{f}}$ Input value is based on an assumption rather than field data

Scyphers (2016) was used to determine the steady-state reference population of adult, sub-adult, and juvenile periwinkles. Due to the limited availability of amphipod data for marshes identified as reference sites for purposes of comparison to restored sites in coastal Louisiana, the reference density for amphipods was derived from three studies of salt marshes spanning the northern Gulf of Mexico (Baumann et al. 2018).

\section{Vegetation and Faunal Function (FWP)}

A recovery trajectory describes how a resource responds to restoration through time. In this REA application, the recovery trajectories are expressed as a response ratio, or the response of a given metric at a restored site compared to a reference site over time, with performance capped at $100 \%$ of reference conditions. For the Barataria Bay example, we calculated the metric-based function $\left(\varphi_{t}\right)$ in year $t$ for aboveground biomass, belowground biomass, total live cover, amphipod density, and periwinkle biomass using a series of recovery trajectories based on meta-analysis of empirical data from studies conducted using paired marsh restoration projects and reference marshes in the Gulf of Mexico region, as described in Ebbets et al. (2019) and Baumann et al. (2018). These metrics were selected to represent different components of the marsh ecosystem with a range of different-shaped response curves. The average response ratios for vegetation cover and periwinkle density demonstrate relatively rapid recovery, with equivalence with reference site conditions achieved around 5 years following restoration. On average, aboveground biomass is equivalent to reference conditions immediately following restoration and remains relatively steady throughout the life of the project. By contrast, belowground biomass requires 17 years to achieve equivalence with reference conditions. Amphipod density at restored marshes never achieves equivalence and is best represented as a uniform response of $48 \%$ for all years following restoration. Additional REA models could also be developed for other marsh components such as nekton or bird communities/ utilization of the restored marsh, depending on the 
restoration project benefits of interest for each individual model application.

Based on the recovery curves for vegetation parameters developed by Ebbets et al. (2019), for aboveground biomass, $\varphi_{t}$ is equal to the reference value $\left(728 \mathrm{~g} \mathrm{~m}^{-2}\right)$ for the initial 17 years of the project, while in the final 3 years of the 20 -year project life, $\varphi_{t}$ gradually decreases to $699 \mathrm{~g} \mathrm{~m}^{-2}$ by year 20 . For belowground biomass, $\varphi_{t}$ is $6554 \mathrm{~g} \mathrm{~m}^{-3}$ in year 1 and increases linearly to reference $\left(14,205 \mathrm{~g} \mathrm{~m}^{-3}\right)$ in years $18-20$. For total live cover, $\varphi_{t}$ is $16.8 \%$ in year 1 and increases linearly to reference cover of $41 \%$ in years 5 and 6 , followed by a more gradual linear decline, with a value of $22 \%$ in year 20 . Based on the recovery curve developed for amphipods and periwinkles by Baumann et al. (2018), $\varphi_{t}$ is 620 amphipods $\mathrm{m}^{-2}$ in each year of the project. Because periwinkles are long-lived invertebrates with a lifespan of 10 years or more, $\varphi_{t}$ is quantified as the annual addition of new biomass to the marsh surface. In addition to the recovery trajectory and reference density, information on survivorship and relationships between biomass and shell length were also used to calculate function. For periwinkles, annual addition of biomass to the marsh surface is low $\left(<1 \mathrm{~g} \mathrm{~m}^{-2}\right)$ over the first 3 years, then increases to 5 and $18 \mathrm{~g} \mathrm{~m}^{-2}$ in years 4 and 5 , respectively. The restored marsh reaches a steady-state annual addition of biomass of $25 \mathrm{~g} \mathrm{~m}^{-2} \mathrm{y}^{-1}$ in year 6 .

\section{Construction Completion Date (FWP and FWOP)}

The date when construction is complete affects the magnitude of benefits generated by a project due to discounting of future project benefits - the farther into the future that a project is implemented, the lower the present value of the project's benefits. We derived a series of input values for this parameter using data from the Louisiana CWPPRA program (Table 2; for information on the derivation methods, see Online Resource 1). For the Barataria Bay example, we used a time to construction completion of 7.9 years, consistent with our derived value for marsh creation projects (Table 1). We assumed a base year of 2016, resulting in a project start date (i.e., construction completion date) of 2024.

\section{Annual Percent Loss of Marsh Platform (FWOP)}

For simplicity, Fig. 2 depicts marsh loss as occurring at the marsh edge; however, marsh loss in the model is not spatially explicit and can occur anywhere within the project area via any marsh loss process. To estimate baseline (FWOP) marsh platform loss rates for Louisiana, we used an analysis conducted by the USGS (Couvillion et al., unpublished data) for all Louisiana marshes. Previously published estimates of coastal land loss by basin derived from 1975 to 2010 satellite imagery (Couvillion et al. 2011) were analyzed by coastal vegetation type (Couvillion et al. 2017; Hartley et al. 2017) based on vegetation types defined by Chabreck and Linscombe $(1978,1988,1997)$ and Sasser et al. $(2008,2014)$ (Table 3). Land and water were delineated across the vegetation types and basins for each year, and a rate of change in the area of each vegetation type was calculated for each basin using linear regression. To simplify interpretation, boundaries between vegetation types were held constant over time, with the boundary set in the first year for which data are available. Therefore, a negative change rate for a given vegetation type represents only loss of marsh and not conversion to another vegetation type (Brady Couvillion, personal communication, February 10, 2016).

Average annual marsh platform loss rates were found to be higher for higher salinity marshes and varied considerably by basin. The annual FWOP marsh platform loss rate calculated for salt marsh in Barataria Bay was $-1.51 \%$ (Table 1). For a comparison of these basin-wide marsh platform loss rates to loss rates for areas considered for restoration, see Online Resource 2.

\section{FWP Marsh Platform Loss Reduction}

We calculated the FWP marsh platform loss rate by multiplying the FWOP marsh platform loss rate by the percent reduction in marsh platform loss afforded by the restoration project (see Eq. 6). As limited published data exist for this parameter, we adopted the CWPPRA program's assumption of a 50\% reduction in the FWOP rate of marsh platform loss (LCWCRTF 2014) and applied this reduced rate of marsh platform loss uniformly throughout the project life and the project area.
Table 2 Time from project conception through construction completion (years) by project type, based on CWPPRA data. Time to construction values presented as mean \pm standard error. An additional year is added to the mean for development of basic project information

\begin{tabular}{llllll}
\hline Project type & \multicolumn{2}{l}{ CWPPRA Phase 1 and 2 (Years) } & $n$ & $\begin{array}{l}\text { Time to construction } \\
\text { completion (years) }\end{array}$ \\
\hline Marsh creation & 6.9 & \pm & 0.5 & 23 & 7.9 \\
Hydrologic restoration & 8.1 & \pm & 1.4 & 23 & 9.1 \\
Shoreline protection & 6.4 & \pm & 0.8 & 24 & 7.4 \\
Average & 7.1 & \pm & 0.9 & 70 & 8.1 \\
\hline
\end{tabular}


Table 3 Annual marsh platform loss rates (percent per year) by Louisiana basin and marsh vegetation type, 1975-2010. Negative values indicate marsh platform loss, while positive values denote accretion and marsh expansion. Averages for basin and vegetation type are provided as both simple averages (Average) and averages weighted by basin or vegetation type area (Weighted Average). Data provided by USGS (Couvillion et al., unpublished data)

\begin{tabular}{lllllll}
\hline Basin & $\begin{array}{l}\text { Salt } \\
(\%)\end{array}$ & $\begin{array}{l}\text { Brackish } \\
(\%)\end{array}$ & $\begin{array}{l}\text { Intermediate } \\
(\%)\end{array}$ & $\begin{array}{l}\text { Fresh } \\
(\%)\end{array}$ & $\begin{array}{l}\text { Average } \\
(\%)\end{array}$ & $\begin{array}{l}\text { Weighted average } \\
(\%)\end{array}$ \\
\hline $\begin{array}{l}\text { Atchafalaya } \\
\quad \text { Delta }\end{array}$ & -0.86 & -1.05 & - & 0.66 & -0.32 & 0.34 \\
$\begin{array}{l}\text { Barataria Bay } \\
\text { Breton Sound }\end{array}$ & -1.51 & -1.06 & -0.60 & -0.03 & -0.64 & -0.52 \\
Calcasieu/Sabine & -0.81 & -0.67 & -1.14 & -0.18 & -0.70 & -0.84 \\
Mermentau & -0.20 & -0.21 & -0.15 & -0.17 & -0.18 & -0.18 \\
Miss. River & -2.69 & -0.62 & 0.18 & -0.15 & -0.27 & -0.26 \\
$\quad$ Delta & -0.73 & -0.47 & -0.30 & 0.95 & -0.54 & 0.17 \\
Pontchartrain & -1.08 & -0.73 & -0.73 & -0.07 & -0.54 & -0.46 \\
Terrebonne Bay & -0.71 & -0.26 & -0.27 & -0.07 & -0.27 & -0.20 \\
$\begin{array}{l}\text { Teche/Vermilion } \\
\text { Average }\end{array}$ & -0.98 & -0.61 & -0.41 & 0.12 & & \\
Weighted & -0.97 & -0.54 & -0.36 & 0.00 & & \\
$\quad$ Average & & & & & & \\
\hline
\end{tabular}

\section{Percent Marsh (FWOP)}

We used CWPPRA WVA data to account for the area of existing marsh within a project footprint prior to restoration (percent marsh FWOP in Fig. 2). Variable 1 from the Coastal Marsh Community Model represents the percent of the project site covered by emergent vegetation (LCWCRTF 2014) and provided the best regionally-specific estimate for this parameter for the Barataria Bay example.

The WVA percent emergent vegetation variable is determined by the percent of land within the project footprint derived from aerial or Landsat satellite imagery collected

Table 4 Average percent marsh within project footprints prior to construction. Values represent mean and standard error by vegetation and project types based on CWPRRA WVA project data

\begin{tabular}{lcccc}
\hline Vegetation type & \multicolumn{2}{l}{ Percent marsh } & $n$ \\
\hline Marsh creation & & & & \\
Salt & $20 \%$ & \pm & 6 & 8 \\
Brackish & $23 \%$ & \pm & 3 & 17 \\
Intermediate & $31 \%$ & \pm & 4 & 15 \\
Fresh & $3 \%$ & \pm & 2 & 13 \\
Average & $20 \%$ & \pm & 2 & 53 \\
Shoreline protection & & & \\
Salt & $58 \%$ & \pm & 11 & 7 \\
Brackish & $51 \%$ & \pm & 6 & 11 \\
Intermediate & $70 \%$ & \pm & 7 & 14 \\
Fresh & $41 \%$ & \pm & 7 & 9 \\
Average & $57 \%$ & \pm & 4 & 41 \\
Hydrologic restoration & & & \\
Salt & $53 \%$ & \pm & 7 & 7 \\
Brackish & $53 \%$ & \pm & 5 & 23 \\
Intermediate & $60 \%$ & \pm & 5 & 15 \\
Fresh & $61 \%$ & \pm & 7 & 12 \\
Average & $57 \%$ & \pm & 3 & 57 \\
\hline & & &
\end{tabular}

immediately prior to project implementation (Brady Couvillion, personal communication, February 10, 2016). The project footprint is defined as the area where measurable biological impact is expected to occur as a result of project implementation. To create a set of potential input values for marsh restoration projects in coastal Louisiana, we calculated percent marsh for each vegetation type for three project types commonly used in coastal Louisiana: marsh creation, shoreline protection, and hydrologic restoration (Table 4). Percent marsh was lower for marsh creation compared to the other two project types and there was no clear trend across vegetation types.

For the Barataria Bay model, we selected a value of $20 \%$, consistent with the value for salt marsh creation projects (Table 1). It is assumed that this $20 \%$ of the project footprint provides benefits equivalent to a reference marsh and these benefits are therefore subtracted from the FWP benefits to calculate net project benefits. The model applies a constant percent marsh over the remaining marsh platform as the area of the marsh platform decreases over the life of the project in the FWOP scenario. While we assumed that the existing marsh was equivalent to a reference marsh in this example, it is also possible to apply a lower percent function if sitespecific data suggest that the existing marsh is degraded relative to reference conditions. In this case, the percent function of the existing marsh would be multiplied by the percent marsh and the other terms in Eq. 1 to yield the quantity of benefits expected in the FWOP scenario for a particular year.

\section{Percent Marsh (FWP)}

For marsh creation and enhancement projects, it is assumed that the FWP percent marsh is $100 \%$ beginning with the first year of the project life. This assumption does not imply that the entire project area functions as a reference marsh in year 1 , 
but rather that the entire project area is marsh platform rather than shallow open water. The FWP percent marsh could be adjusted to apply this model to other types of restoration projects that do not result in a direct increase in the area of marsh within the project footprint. For example, a shoreline protection project could have the same percent marsh value for FWP as for FWOP, assuming the objective of the project was to reduce erosion of an existing marsh. In addition, the FWP percent marsh could be adjusted for projects that are designed to include a non-trivial percent area of shallow water features such as tidal creeks or ponds. Because the model presently assumes that FWP percent marsh is $100 \%$, there is no FWP percent marsh term in the model.

\section{Sensitivity Analysis}

A series of one-at-a-time perturbation-based sensitivity analyses were conducted to investigate the relative effect of each input parameter on the model output and explore uncertainty in model outputs across the reasonable range of input parameter values. One-at-a-time perturbation is the simplest form of model sensitivity analysis and is a quick method to obtain preliminary insights into the relative importance of input variables and degree of uncertainty in model outputs (Hamby 1994; Pianosi et al. 2016). In this method, each input parameter is varied sequentially by a fixed percentage while holding all other input parameters constant, to observe the impact of each perturbation on the model output. The Barataria Bay base model was run multiple times, varying each input parameter \pm $50 \%$. This analysis was conducted for the belowground biomass, periwinkle, and amphipod models, representing three different recovery trajectories: slow and linear recovery (belowground biomass), a two-phase recovery trajectory (periwinkles), and a partial but immediate recovery (amphipods).

Additional analyses were conducted for all five models (three vegetation components, periwinkles, and amphipods) to determine the reasonable range of model results considering the uncertainty associated with each input. We calculated maximum and minimum reasonable marsh benefits based on the best available information characterizing the variability of each input parameter, including measures of uncertainty of data used to derive the base input values, alternate data sources for input values, and best professional judgment. When varying the inputs using measures of uncertainty, we typically added $\pm 100 \%$ of the standard deviation or standard error, depending on which measure was available for the data. For percent function, values were capped at one so that the maximum function did not exceed reference conditions. Given the high variability associated with the periwinkle and amphipod reference densities and in order to avoid a calculation of zero net benefits in the minimum reasonable scenario, values of \pm $50 \%$ of the standard deviation (periwinkles) or the input value (amphipods) were used. For FWOP marsh platform loss, a marsh platform loss rate derived from CWPPRA salt marsh creation projects was substituted for the basin-derived values used in the base scenario, to compare the impact of these different data sources on the model outputs. For other inputs, such as FWP relative marsh platform loss, we relied on best professional judgment to determine a reasonable range of potential input values. When we determined only one alternate input value for a given input, we used the base scenario value for either the maximum or minimum reasonable scenario, as appropriate (i.e., FWOP marsh platform loss). Alternate input values were then combined in such a way to calculate maximum and minimum reasonable marsh benefits.

\section{Results}

\section{Net Benefits for a Hypothetical Marsh Creation Project in Barataria Bay, Louisiana}

The modeled annual net benefits of the hypothetical salt marsh creation project in Barataria Bay illustrate the unique trajectory of each marsh component (Figs. 3 through 5). It should be emphasized that annual benefits per unit area represent the average benefits per unit area over the initial project area, not only over the remaining marsh. Although results are typically expressed as present-value net benefits for the purpose of NRDA restoration scaling, we also present the undiscounted results for FWOP and FWP benefits, which may be more useful for conceptualizing the amount of benefits provided each year in each of these two scenarios and for understanding the derivation of the present value net benefits results. Undiscounted FWOP benefits declined gradually over time for each metric due to loss of the marsh platform. The shape of the undiscounted FWP benefits curve was dependent on the recovery trajectory and the rate of loss of the marsh platform. For metrics with a recovery trajectory slope of 0 (e.g., aboveground biomass for most of the project life and amphipods), annual undiscounted FWP benefits decreased over time due to the rate of marsh platform loss. For metrics with a positive recovery trajectory slope (e.g., belowground biomass, percent cover for the first 5 years of the project life, periwinkles for the first 6 years) annual undiscounted FWP benefits increased over time. Present value net benefits displayed a shallower or more negative slope than undiscounted net benefits because benefits in future years are considered progressively less valuable than the same benefits in the current year. Periwinkle net benefits were negative in the first 4 years of the project life due to the small amount of benefits provided by the existing marsh in the FWOP scenario and the nearly zero benefits provided by the restored marsh during this early time period.

In a NRDA restoration scaling context, the modeled benefits on net present-value basis over the entire project life would 
Fig. 3 Modeled aboveground and belowground biomass benefits of a created salt marsh in Barataria Bay, Louisiana, over the project life. Benefits are expressed in terms of initial project area, not in terms of remaining marsh area. $Q_{R}$, represents FWP benefits, while $Q_{I}$ represents FWOP benefits. $Q_{R}-Q_{I}$ represents undiscounted net benefits, and $Q_{N}$ represents present value net benefits (in 2016 terms)
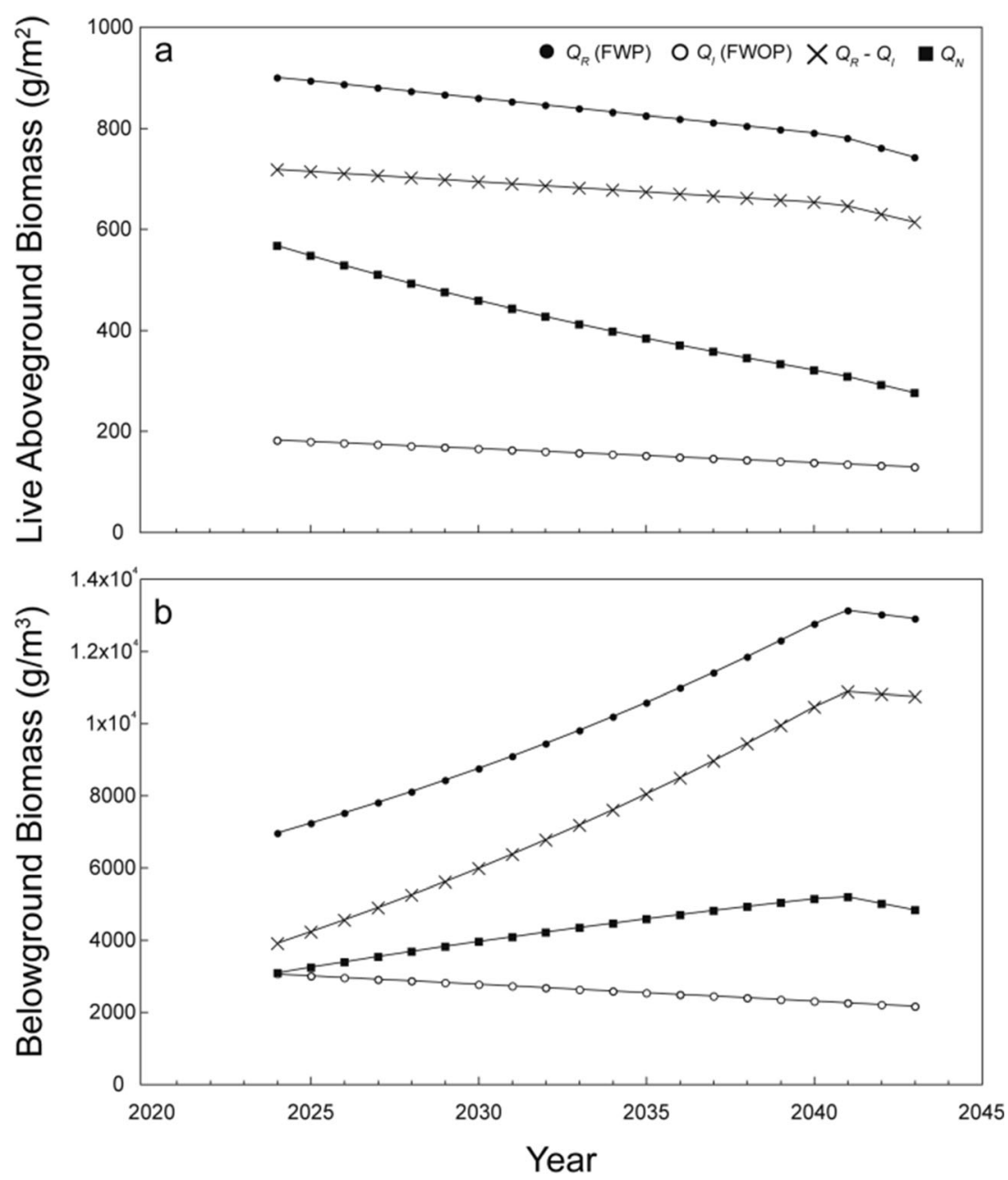

be used to calculate the amount of restoration required to compensate for natural resource injuries (Table 5). It should be emphasized that the total live cover result of $338 \% \mathrm{~m}^{-2}$ is interpreted that over a 20 -year project life, $1 \mathrm{~m}^{2}$ of restoration project area yielded $338 \%$ more total live cover, as compared to the same area in the absence of a restoration project (FWOP).

\section{Sensitivity Analysis}

The only input that yielded a 1:1 relationship to model output was the reference value: a $50 \%$ increase in reference density resulted in a $50 \%$ increase in the model output, whereas a $50 \%$ decrease in the value of the input resulted in a $50 \%$ decrease in the output (Online Resources 3-5). The effects of changing other model inputs were not easily predicted and depended instead on the relative magnitude of each of the other inputs. For instance, the relative effect of varying project life by \pm $50 \%$ was greater for belowground biomass $(a+50 \%$ change in project life resulted in a $46 \%$ change in model output, while $\mathrm{a}-50 \%$ change resulted in a $-57 \%$ change in model output) and periwinkles (model output changes of $+43 \%$ and $-61 \%$ ) compared to amphipods (model output changes of $+31 \%$ and $-42 \%)$. This difference is due largely to the fact that the recovery trajectory for belowground biomass and periwinkles indicated recovery to reference values over time, whereas the amphipod recovery trajectory indicated a uniform percent function of $48 \%$ compared to reference values throughout the project life.

In general, we found that the meta-analysis-derived recovery trajectory exerted a large influence on the model output, equal to or greater than the influence of the reference values for the range of values modeled. Across all models, FWOP marsh platform loss and the reduction of marsh platform loss in the FWP scenario had the least impact on model output $(6 \%$ or less change in results with $\mathrm{a} \pm 50 \%$ change in these inputs). Because marsh loss rates vary across Louisiana basins and marsh types by considerably more than $\pm 50 \%$, this finding should not be interpreted to suggest that marsh platform loss is not an important consideration in siting and selection of marsh restoration projects. Percent marsh in the FWOP scenario had a moderate effect on output with $\mathrm{a} \pm 50 \%$ change in input values resulting in a $17-32 \%$ change in results. These results indicate that, for the range of values considered in the 
Fig. 4 Modeled vegetation cover benefits of a created salt marsh in Barataria Bay, Louisiana, over the project life. Benefits are expressed in terms of initial project area, not in terms of remaining marsh area. $Q_{R}$ represents FWP benefits, while $Q_{I}$ represents FWOP benefits. $Q_{R}-$ $Q_{I}$ represents undiscounted net benefits, and $Q_{N}$ represents present value net benefits (in 2016 terms)

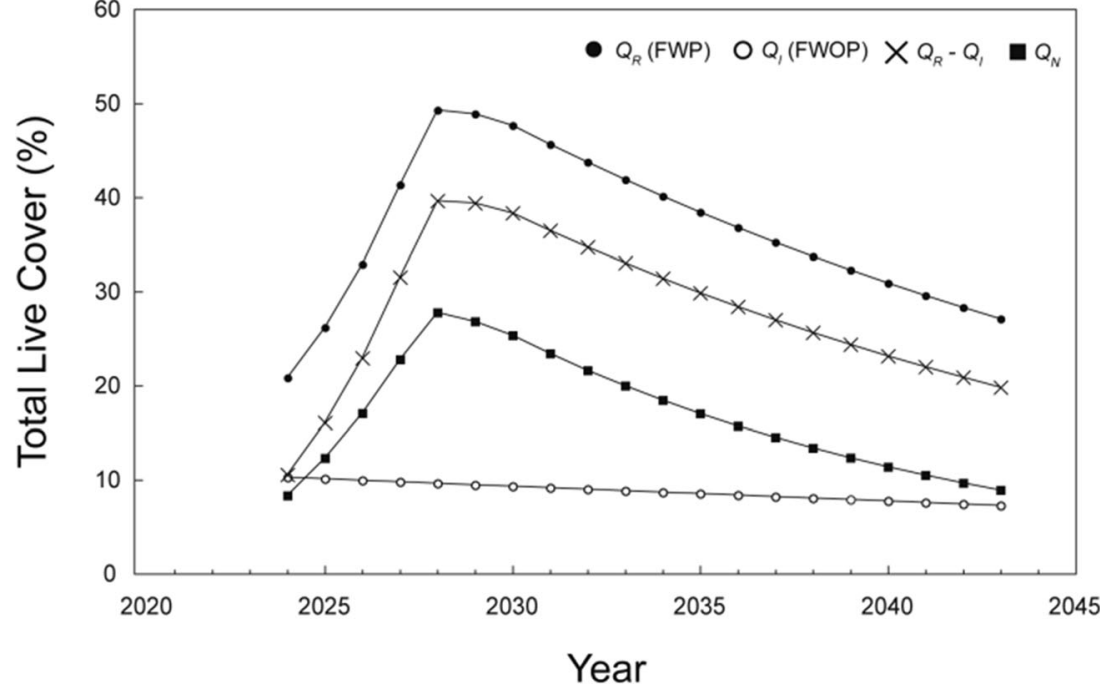

sensitivity analysis, reference values and recovery trajectories had the greatest effect on results, followed by FWOP percent marsh. Future applications of the model should focus the greatest effort on these three inputs, including evaluating whether the input values presented here are appropriate for future intended model use (e.g., based on the geographic location and characteristics of the restoration project) or whether more project-specific values can be derived.
Fig. 5 Modeled periwinkle and amphipod benefits of a created salt marsh in Barataria Bay, Louisiana, over the project life. Benefits are expressed in terms of initial project area, not in terms of remaining marsh area. $Q_{R}$ represents FWP benefits, while $Q_{I}$ represents FWOP benefits. $Q_{R}-$ $Q_{I}$ represents undiscounted net benefits, and $Q_{N}$ represents present value net benefits (in 2016 terms)
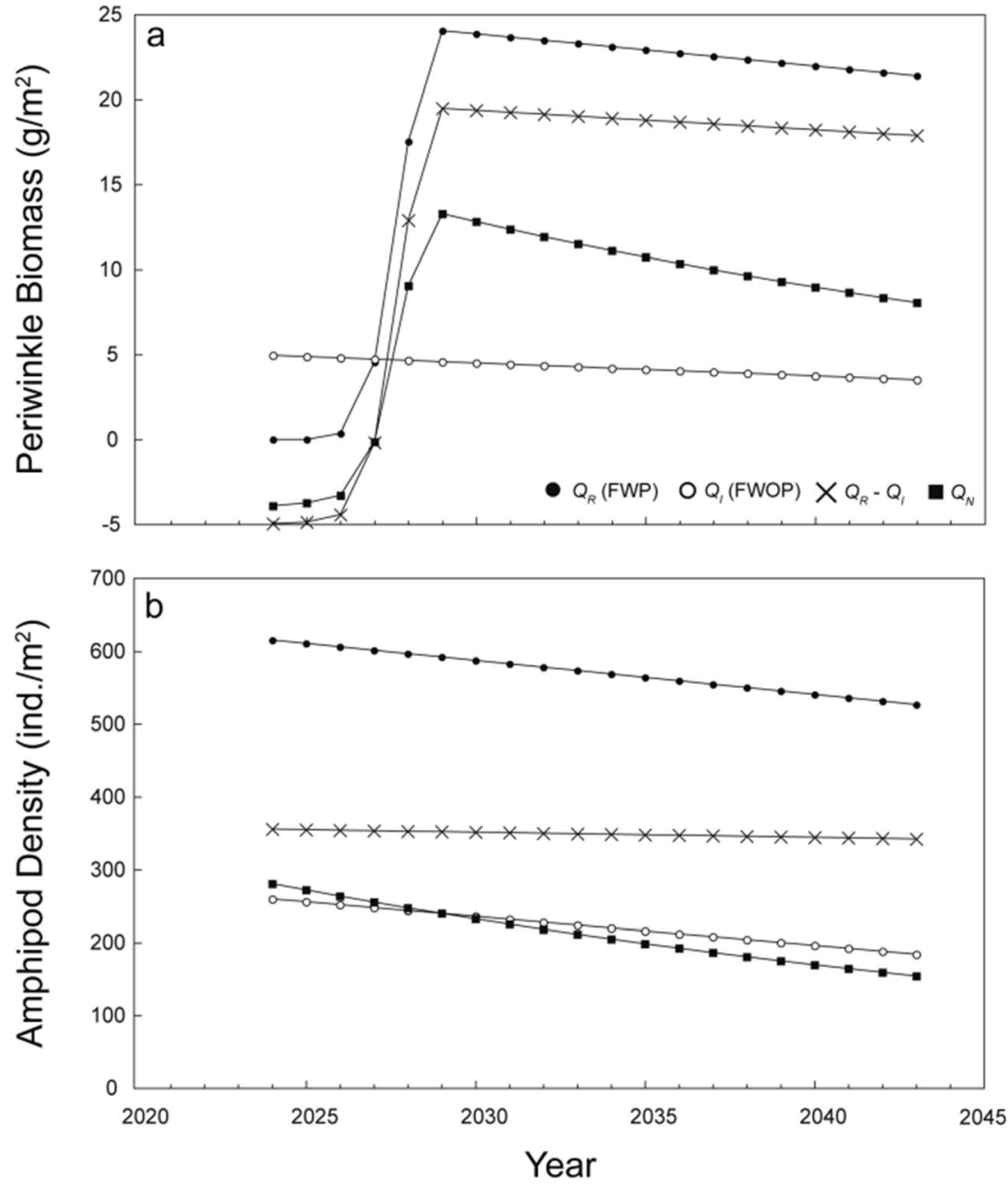
Table 5 Modeled benefits (total present value net benefits) of a created salt marsh in Barataria Bay, Louisiana, over the entire project life

\begin{tabular}{lc}
\hline Marsh resource & Project benefit $^{\mathrm{a}}$ \\
\hline Vegetation & \\
Aboveground biomass (live, dry weight) & $8247 \mathrm{~g} \mathrm{~m}^{-2}$ \\
Belowground biomass (total, dry weight) & $86,102 \mathrm{~g} \mathrm{~m}^{-3}$ \\
Total live cover & $338 \% \mathrm{~m}^{-2}$; see Fig. 4 \\
Fauna & for interpretation \\
Periwinkle (wet weight) & $155 \mathrm{~g} \mathrm{~m}^{-2}$ \\
Amphipod & $4231 \mathrm{ind} \mathrm{m}^{-2}$ \\
\hline
\end{tabular}

${ }^{\text {a }}$ Project benefits are expressed in terms of initial project area, not in terms of remaining marsh area
The sensitivity analysis to determine the reasonable upper and lower bounds for the vegetation metrics indicated maximum reasonable outputs of 20 to $27 \%$ increase over base model results and minimum reasonable outputs of 16 to $22 \%$ less than base model results (Online Resource 6). The faunal groups had a wider range of reasonable outputs compared to the vegetation metrics (Online Resource 7). The maximum reasonable outputs for periwinkles and amphipods represented an increase of $72 \%$ and $164 \%$, respectively, compared to base model results, while the minimum reasonable outputs represented a decrease of $91 \%$ and $84 \%$ compared to base outputs, respectively. Variability in the reference amphipod density was high and likely attributable to differences in reported taxa in the literature, natural and seasonal variability in the populations, and the plant density and species composition at the sampling site, among other factors.

\section{Discussion}

\section{Potential Model Uses}

The methods, model inputs, and results presented here may be applied to future NRDAs in the Gulf of Mexico, especially within Louisiana. In restoration scaling, these model results may be paired with natural resource injury results to determine the area of restoration required to compensate for the injuries. Ideally, site-specific information should be used to develop model inputs whenever possible. However, specific restoration sites are not always identified prior to scaling restoration requirements for natural resource injuries, and the generalized model parameterization presented in this paper could be used in lieu of site-specific parameter inputs in these situations.

Although REA was developed as a tool to scale restoration projects in an NRDA context, the model has additional potential uses. For instance, the establishment of anticipated benefits, expressed in terms of vegetation and fauna metrics that can be readily monitored, could be used to set reasonable restoration targets and performance criteria for restoration projects (Hackney 2000; Steyer et al. 2006; Weinstein et al.
2001). For this purpose, we recommend the use of annual, undiscounted FWP benefits, or, if reference site data are available, annual, undiscounted net benefits.

The selection of marsh restoration projects is often a complex decision based on considerations such as the nexus to injuries, predicted ability to compensate for permitted impacts, synergies with other restoration projects, benefits to other habitats and resources, stakeholder input and perceptions, and regulatory considerations. This model could assist with restoration project selection by providing an estimate of the quantitative benefits expected for various potential projects, providing an objective means of comparison between potential sites.

However, there is large uncertainty associated with model results, as highlighted by the range between maximum and minimum reasonable net benefits. Because of this uncertainty, it is important that the user's selection of input values reflect the intended use of the model results and the user's tolerance for the over- or under-estimation of benefits. For instance, if a restoration project is intended to mitigate environmental harm (i.e., compensatory mitigation) or compensate for injuries in an NRDA context, regulators or natural resource trustees may opt to adopt a more cautious approach than presented in our base model runs and select input values that assume fewer environmental benefits based on the uncertainty associated with the input values (Levrel et al. 2012; Weinstein et al. 2001). Ebbets et al. (2019) suggest that it may be appropriate in an NRDA context to use the 20th percentile of recovery trajectory data rather than the mean. By contrast, if the model is used to help set restoration targets for individual projects, it may be more appropriate to identify a range of acceptable targets for each marsh component rather than definitive performance thresholds, to better account for natural variability (Hackney 2000; Short et al. 2000).

Modeling multiple components of the marsh system provides a more complete depiction of marsh restoration benefits than modeling a single component (Desvousges et al. 2018). Marsh components often respond differentially to restoration, with some elements recovering faster than others. While aboveground biomass and vegetation cover may attain parity 
with reference conditions within a few years following restoration (Armitage et al. 2014; Broome et al. 2002; Ebbets et al. 2019; Edwards and Proffitt 2003; LaSalle et al. 1991), other components of the marsh may recover more slowly (Minello and Zimmerman 1992; Craft et al. 1999; Craft et al. 2002; Craft et al. 2003; Ebbets et al. 2019; Hollweg et al. 2019) or never return to reference conditions within the project life or monitoring timeframe (Baumann et al. 2018; Moreno-Mateos et al. 2012; Zeug et al. 2007). These varying recovery patterns, which have a strong effect on calculated net benefits, highlight the importance of considering multiple marsh components in the recovery of a restored marsh (Hollweg et al. 2019; Strange et al. 2002), including components such as belowground biomass, soil biogeochemical processes, and macroinvertebrate populations that tend to be slower to recover (Baumann et al. 2018; Craft et al. 2003; Ebbets et al. 2019; Moreno-Mateos et al. 2012; Zeug et al. 2007).

For a discussion of potential model adaptations, including using a HEA rather than a REA model, see Online Resource 8.

\section{Uncertainties}

The quantitative nature of HEA and REA outputs can create a false sense of accuracy if uncertainties are not presented (Dunford et al. 2004). The inputs presented in this paper are associated with varying degrees of uncertainty and this uncertainty is carried forward into relatively large uncertainty in the model results for some marsh components, particularly for periwinkles and amphipods. The simple sensitivity analysis conducted on the Barataria Bay model suggests that many of the input parameters have a non-linear relationship with the output value and likely interact in ways that may not be fully illustrated by one-at-a-time perturbations. Future improvements to the model should include further examination of input parameter importance and output variability using more advanced measures of global sensitivity, which consider the range of variability across all input parameters simultaneously. There are limited examples of sensitivity analyses of HEA and REA models in the literature (Dunford et al. 2004; French McCay et al. 2003a, 2003b; French McCay and Rowe 2003), and a more in-depth analysis of parameter importance and uncertainties in model outputs could help identify the most important areas to focus on for future model improvements. Nonetheless, we were able to identify several areas of uncertainty for this particular REA model framework based on the results of our preliminary sensitivity analyses and limitations of the data available to construct the Barataria Bay model.

Significant uncertainty is associated with the vegetation and fauna recovery trajectories due to limited data and high natural variability (Baumann et al. 2018; Ebbets et al. 2019). Further, the different methods used to derive the vegetation, periwinkle, and amphipod trajectories highlight that there are multiple approaches to developing a trajectory. Individual trajectories can also be applied to the model in different ways, which is an additional source of model uncertainty. For instance, we capped restored marsh metric-based function at $100 \%$ of the reference marsh value in this example, based on the assumption that values greater than reference do not provide additional benefit, and additional "credit" should not be given for this outcome in an NRDA scaling context. Likewise, in a monitoring context, we assume that the project should only be required to provide the equivalent of reference conditions and not greater. However, there may be circumstances where using uncapped values is more appropriate. An example might be if reference conditions are depressed relative to a "healthy" marsh due to factors other than the contamination affecting the injured marsh. As the sensitivity analysis indicates that the recovery trajectories have a large effect on model results for the ranges of input values we tested, selection of the most appropriate trajectory and how that trajectory is applied in the model are critical factors impacting overall model uncertainty.

Another source of uncertainty is the percent marsh (FWOP) input, which the sensitivity analysis indicates has a moderate effect on model results. This input is highly dependent on the method used to set project boundaries; the calculated percent marsh of a project would decrease if project boundaries are set broadly to encompass more open water. The model also assumes that the metric-based function of a FWOP project area can be estimated by multiplying the FWOP percent marsh and the reference value. The accuracy of this assumption depends on the quality of the existing marsh at a FWOP site. If the existing marsh is degraded (e.g., lower aboveground biomass per unit area compared to a reference marsh), FWOP metric-based function will be overestimated and net benefits will be underestimated.

Another model assumption is that the restored (FWP) project area is entirely covered by marsh in the first year of the project life. This assumption may be relatively reasonable for marsh creation projects, for which CWPPRA defines the project area as the extent of dredged material placement (LCWCRTF 2014). The incorporation of channels, ponds, and other features to add marsh edge and habitat complexity would decrease the amount of vegetated marsh platform within the project area, but inclusion of such features should increase similarity to reference marshes and improve function for nekton that utilize the marsh. While such areas should be excluded from the calculation of marsh area when using this model to calculate benefits for vegetation and marshdependent fauna, they can be included as part of the marsh area if the model is applied to the calculation of benefits for nekton. For other restoration types, the assumption that $100 \%$ of the project site is covered by marsh likely requires reevaluation. If the modeled project site is covered by less than 
$100 \%$ marsh at the start of the project, assuming $100 \%$ coverage will overestimate net benefits.

The extent to which restoration projects reduce future marsh platform loss has not been well established. The assumed 50\% FWP marsh platform loss reduction factor may be low, based on anecdotal evidence from the CWPPRA program (Kevin Roy, personal communication, February 8, 2016). The actual reduction in marsh platform loss of a marsh restoration project is likely to be highly dependent on project design, but if it is greater than the assumed $50 \%$, model results will underestimate marsh benefits. However, for the range of input values used in our sensitivity analysis, this input has a relatively small effect on model results.

Although the sensitivity analysis indicated that FWOP marsh platform loss rates have a relatively small effect on the model results, the FWOP marsh platform loss rates represent another source of uncertainty. The USGS FWOP marsh platform loss rates (Couvillion et al., unpublished data) used in this model are specific to Louisiana and are not likely to be applicable to other geographic regions due to the unique nature of marsh platform loss in Louisiana, which tends to be higher than other parts of the northern Gulf of Mexico (Barras et al. 2003; Steyer et al. 2006). Further, application of a basinspecific marsh platform loss rate assumes that the design of a wetland restoration project does not specifically account for the regional marsh platform loss rate, thus reducing or eliminating the effect of basin-specific FWOP marsh platform loss rates on FWP marsh platform loss rates. Lastly, application of these rates to predict future marsh platform loss assumes that future marsh platform loss rates over the 20-year project life are comparable to past marsh platform loss rates (1975-2010). This may not be an accurate assumption. For instance, Couvillion et al. (2017) observed slowing loss rates in most Louisiana basins in recent years. If future loss rates are slower than past loss rates, the model may underestimate net benefits.

The FWOP marsh platform loss rates used in the model are derived over entire basins and may not be representative of rates in areas selected for marsh restoration projects. Areas of particularly high marsh platform loss may be preferentially selected for marsh restoration projects. Conversely, areas with very high marsh platform loss rates may be avoided for restoration because projects in these areas may not be sustainable. Our comparison of these basin-wide marsh platform loss rates to marsh platform loss rates associated with specific CWPPRA projects indicated that the rates were generally comparable but that the basin-wide rates were typically slightly lower (less marsh platform loss) than the project-specific rates, especially at lower salinities and for marsh creation and hydrologic restoration (rather than shoreline protection) projects. An advantage of the basin-wide rates is that marsh platform loss rates vary considerably by basin. However, these numbers may underestimate actual FWOP marsh platform loss, especially at sites characterized by lower salinities. If the FWOP marsh platform loss rate, which is also used to derive the FWP marsh platform loss rate, is higher than what is used in the model, model results may overestimate net benefits.

\section{Recommended Future Research}

Future efforts to refine this model should focus on the inputs that have the highest uncertainty or that have the most influence on model results. The limited data informing the recovery trajectories used for this model, combined with wide natural variability, highlight the need for additional, longer-term monitoring data at restored marsh sites (Baumann et al. 2018; Ebbets et al. 2019; Hollweg et al. 2019). Monitoring of vegetation and fauna metrics at mature sites (e.g., > 5-10 years old) would improve understanding of the performance of older sites without requiring long-term studies. In Louisiana, CWPPRA sites provide a potential source of useful data because they are numerous, their locations are well known, and abundant data on reference marshes are available through the Louisiana Coastwide Reference Monitoring System (CRMS). In addition to collecting new field data to improve recovery trajectories, additional data mining could be conducted to develop recovery trajectories for other components of the marsh, such as birds and terrestrial arthropods, to more fully represent the ecological functioning of a marsh.

The recovery trajectories for marsh vegetation and soil parameters used for this model were developed based on data from marsh creation and thin-layer placement projects using dredged material and should not be applied to other types of marsh restoration projects where recovery of the vegetation community and soils is not an expected outcome of the project (e.g., shoreline protection, hydrologic restoration). While the recovery trajectories for marsh fauna do include data for hydrologic restoration, there may be value in developing separate recovery trajectories for each type of restoration project in the future, as more data become available for these projects.

Although the reduction in baseline marsh platform loss that is afforded by the restoration project has a relatively minor effect on the calculation of net benefits for the range of values modeled, it is the primary input that was not derived from field data but rather represents a gross assumption. There are opportunities to refine this input in the future. With a gaining interest in living shorelines projects, we expect an abundance of potentially useful information on the effect of this project type on shoreline change and degree of marsh platform protection. Another potential data source to refine this input is CWPPRA aerial imagery. To date, these data are insufficient to derive reduction in marsh platform loss factors (Kevin Roy, personal communication, February 8,2016 ), but in the future, this may be a useful data source for marsh creation and hydrologic restoration project types. 
In general, efforts to refine the model should reflect sitespecific conditions or concerns. For instance, because marsh platform loss is an issue of great concern in Louisiana, we devoted considerable attention to deriving marsh platform loss values, and model users may wish to further refine these values. Model application in other geographic regions or environmental settings may warrant additional model modifications or refinements. For instance, although we provide a range of values based on vegetation type for several inputs (FWOP marsh platform loss, FWOP percent marsh), other inputs are focused exclusively on salt marshes (reference values for vegetation, periwinkle, and amphipod metrics, and recovery trajectories for periwinkles and amphipods). Additional data collection and analysis will be valuable to adapt this model for use for lower salinity marshes.

Acknowledgments The authors gratefully acknowledge the technical input of the following individuals: Tom Minello, John Kern, Natalie McLenaghan, Mary Baker, Jim Turek, and Tom Moore of the National Oceanic and Atmospheric Administration (NOAA), Hal Fravel of Research Planning, Inc., Charles Sasser of Louisiana State University, Mark Hester and Jonathan Willis of University of Louisiana at Lafayette, Diana Lane and Allison Ebbets of Abt Associates, and Sean Powers of University of South Alabama. The advice of Alexandra van Geel of Industrial Economics, Inc., resulted in significant improvements to this manuscript.

The scientific results and conclusion of this publication, as well as any views or opinions expressed herein, are those of the authors and do not necessarily represent the views of the other natural resource Trustees for the BP/Deepwater Horizon NRDA. Any use of trade, firm, or product names is for descriptive purposes only and does not imply endorsement by the U.S. Government.

Funding Information Funding of this study and production of this publication was provided by the Federal and State Natural Resource Agencies' (Trustees') Natural Resource Damage Assessment (NRDA) for the Deepwater Horizon (DWH) oil spill through the National Oceanic and Atmospheric Administration (NOAA) Damage Assessment, Remediation and Restoration Program (DARRP) (NOAA Contract No. AB133C-11-CQ-0050).

Open Access This article is licensed under a Creative Commons Attribution 4.0 International License, which permits use, sharing, adaptation, distribution and reproduction in any medium or format, as long as you give appropriate credit to the original author(s) and the source, provide a link to the Creative Commons licence, and indicate if changes were made. The images or other third party material in this article are included in the article's Creative Commons licence, unless indicated otherwise in a credit line to the material. If material is not included in the article's Creative Commons licence and your intended use is not permitted by statutory regulation or exceeds the permitted use, you will need to obtain permission directly from the copyright holder. To view a copy of this licence, visit http://creativecommons.org/licenses/by/4.0/.

\section{References}

Akin, S., and K.O. Winemiller. 2008. Body size and trophic position in a temperate estuarine food web. Acta Oecologica 33: 144-153.
Armitage, A.R., C.-K. Ho, E.N. Madrid, M.T. Bell, and A. Quigg. 2014. The influence of habitat construction technique on the ecological characteristics of a restored brackish marsh. Ecological Engineering 62: 33-42.

Baker, M.C., M.A. Steinhoff, and G.F. Fricano. 2017. Integrated effects of the deepwater horizon oil spill on nearshore ecosystems. Marine Ecology Progress Series 576: 219-234.

Barras, J. A. 2009. Land Area Change and Overview of Major Hurricane Impacts in Coastal Louisiana, 2004-08: U.S. Geological Survey Scientific Investigations Map 3080, scale 1:250,000, 6 p. pamphlet.

Barras, J., S. Beville, D. Britsch, S. Hartley, S. Hawes, J. Johnston, P. Kemp, Q. Kinler, A. Martucci, J. Porthouse, D. Reed, K. Roy, S. Sapkota, and J. Suhayda. 2003. Historical and Projected Coastal Louisiana Land Changes: 1978-2050: U.S. Geological Survey Open-File Report 03-334, 39 p. (Revised January 2004).

Barras, J. A., J. C. Bernier, and R. A. Morton. 2008. Land Area Change in Coastal Louisiana: A Multidecadal Perspective (from 1956 to 2006): U.S. Geological Survey Scientific Investigations Map 3019, scale 1:250,000, 14 p. pamphlet.

Baumann, M.S., G.F. Fricano, K. Fedeli, C. Schlemme, M.C. Christman, and M. Carle. 2018. Recovery of salt marsh invertebrates following habitat restoration: implications for marsh restoration in the northern Gulf of Mexico. Estuaries and Coasts. Special Section: Restoration Benefits in Gulf of Mexico. Published online October 11: 2018. https://doi.org/10.1007/s12237-018-0469-5.

Boesch, D. F., M. N. Josselyn, A. J. Mehta, J. T. Morris, W. K. Nuttle, C. A. Simenstad, and D. J. P. Swift. 1994. Scientific assessment of coastal wetland loss, restoration, and management in Louisiana. Journal of Coastal Research. Special Issue 20: 1-103.

Brinson, M.M., and R. Rheinhardt. 1996. The role of reference wetlands in functional assessment and mitigation. Ecological Applications 6: 69-76.

Broome, S.W., C.B. Craft, and W.A. Toomey Jr. 2002. Soil organic matter effects on Infaunal community structure in restored and created tidal marshes. In Concepts and controversies in tidal marsh ecology, ed. M.P. Weinstein and D.A. Kreeger, 737-747. The Netherlands: Kluwer Academic Publishers.

Burke, J.S. 1995. Role of feeding and prey distribution of summer and southern flounder in selection of estuarine nursery habitats. Journal of Fish Biology 47: 355-366.

Chabreck, R.H., and G. Linscombe. 1978. Vegetative Type Map of the Louisiana Coastal Marshes: Baton Rouge. Louisiana Department of Wildlife and: Fisheries.

Chabreck, R.H., and G. Linscombe. 1988. Vegetative Type Map of the Louisiana Coastal Marshes. Baton Rouge: Louisiana Department of Wildlife and Fisheries, set of 10 maps.

Chabreck, R.H., and G. Linscombe. 1997. Vegetative Type Map of the Louisiana Coastal Marshes: Baton Rouge. Louisiana Department of Wildlife and: Fisheries.

Coastal Protection and Restoration Authority of Louisiana. 2017. Louisiana's Comprehensive Master Plan for a Sustainable Coast. Coastal Protection and Restoration Authority of Louisiana. LA: Baton Rouge.

Cosco Busan Oil Spill Trustees. 2012. Cosco Busan Oil Spill Final Damage Assessment and Restoration Plan/Environmental Assessment. Prepared by California Department of Fish and Game, California State Lands Commission, National Oceanic and Atmospheric Administration, United States Fish and Wildlife Service, National Park Service, Bureau of Land Management.

Couvillion, B. R., J. A. Barras, G. D. Steyer, W. Sleavin, M. Fischer, H. Beck, N. Trahan, B. Griffin, and D. Heckman. 2011. Land Area Change in Coastal Louisiana from 1932 to 2010: U.S. Geological Survey Scientific Investigations Map 3164, scale 1:265,000, 12 p. pamphlet.

Couvillion, B. R., H. Beck, D. Schoolmaster, and M. Fischer. 2017. Land Area Change in Coastal Louisiana 1932 to 2016: U.S. Geological 
Survey Scientific Investigations Map 3381, 16 p. pamphlet, https:// doi.org/10.3133/sim3381.

Craft, C., J. Reader, J.N. Sacco, and S.W. Broome. 1999. Twenty-five years of ecosystem development of constructed Spartina alterniflora (Loisel) marshes. Ecological Applications 9: 14051419.

Craft, C., S. Broome, and C. Campbell. 2002. Fifteen years of vegetation and soil development after brackish-water marsh creation. Restoration Ecology 10: 248-258.

Craft, C., P. Megonigal, S. Broome, J. Stevenson, R. Freese, J. Cornell, L. Zheng, and J. Sacco. 2003. The pace of ecosystem development of constructed Spartina alterniflora marshes. Ecological Applications 13: $1417-1432$

Dahl, T. E. and S. M. Stedman. 2013. Status and Trends of Wetlands in the Coastal Watersheds of the Conterminous United States, 2004 to 2009. U.S. Department of the Interior, Fish and Wildlife Service and National Oceanic and Atmospheric Administration, National Marine Fisheries Service. http://www.fws.gov/wetlands/ Documents/Status-and-Trends-of-Wetlands-in-the-ConterminousUnited-States-2004-to-2009.pdf.

Day, J.W., Jr., L.D. Britsch, S.R. Hawes, G.P. Shaffer, D.J. Reed, and D. Cahoon. 2000. Pattern and process of land loss in the Mississippi Delta: a spatial and temporal analysis of wetland habitat change. Estuaries 23: 425-438.

Day, J.W., Jr., D.F. Boesch, E.J. Clairain, G.P. Kemp, S.B. Laska, W.J. Mitsch, K. Orth, H. Mashriqui, D.J. Reed, L. Shabman, C.A. Simenstad, B.J. Streever, R.R. Twilley, C.C. Watson, J.T. Wells, and D.F. Whigham. 2007. Restoration of the Mississippi Delta: lessons from hurricanes Katrina and Rita. Science 315 (5819): 16791684.

Deepwater Horizon Natural Resource Damage Assessment Trustees (DWH NRDA Trustees). 2016. Deepwater Horizon oil spill: Final Programmatic Damage Assessment and Restoration Plan and Final Programmatic Environmental Impact Statement. Retrieved from http://www.gulfspillrestoration.noaa.gov/restoration-planning/gulfplan on 2/29/2016.

Deepwater Horizon Natural Resource Damage Assessment Trustees (DWH NRDA Trustees), Louisiana Trustee Implementation Group. 2018. Strategic Restoration Plan and Environmental Assessment \#3: Restoration of Wetlands, Coastal, and Nearshore Habitats in the Barataria Basin, Louisiana. Retrieved from https:// www.gulfspillrestoration.noaa.gov/2018/03/louisiana-trusteesfinalize-barataria-strategic-restoration-plan on 6/26/2019.

Desvousges, W.H., N. Gard, H.J. Michael, and A.D. Chance. 2018. Habitat and resource equivalency analysis: a critical assessment. Ecological Economics 143: 74-89.

Dunford, R.W., T.C. Ginn, and W.H. Desvousges. 2004. The use of habitat equivalency analysis in natural resource damage assessments. Ecological Economics 48: 49-70.

Ebbets, A.L., D.R. Lane, P. Dixon, T.A. Hollweg, M.T. Huisenga, and J. Gurevitch. 2019. Using meta-analysis to develop evidence-based recovery trajectories of vegetation and soils in restored wetlands in the northern Gulf of Mexico. Estuaries and Coasts. Special Section: Restoration Benefits in Gulf of Mexico. Published online April 3: 2019-2019. https://doi.org/10.1007/s12237-019-00536-y.

Edwards, K.R., and C.E. Proffitt. 2003. Comparison of wetland structural characteristics between created and natural salt marshes in Southwest Louisiana, USA. Wetlands 23: 344-356.

European Commission. 2007. Resource Equivalency Methods for Assessing Environmental Damage in the EU. Sixth Framework Programme, Review Report on Resource Equivalence Methods and Applications.

Ford, M.A., D.R. Cahoon, and J.C. Lynch. 1999. Restoring marsh elevation in a rapidly subsiding salt marsh by thin-layer deposition of dredged material. Ecological Engineering 12: 189-205.
French McCay, D., and J.J. Rowe. 2003. Habitat restoration as mitigation for lost production at multiple trophic levels. Marine Ecology Progress Series 264: 233-247.

French McCay, D., M. Gibson, and J.S. Cobb. 2003a. Scaling restoration of American lobsters: Combined demographic and discounting model for an exploited species. Marine Ecology Progress Series 264: 177-196.

French McCay, D., C.H. Peterson, J.T. DeAlteris, and J. Catena. 2003b. Restoration that targets function as opposed to structure: replacing lost bivalve production and filtration. Marine Ecology Progress Series 264: 197-212.

Gala, W. R., R. W. Hill, and L. A. Hostetter. 2008. Use of Habitat Equivalency Analysis (HEA) to determine the environmentally superior project alternative. Pages 1393-1401 in Society of Petroleum Engineers- 9th International Conference on Health, Safety and Environment in Oil and Gas Exploration and Production 2008 "In Search of Sustainable Excellence".

Hackney, C.T. 2000. Restoration of coastal habitats: expectation and reality. Ecological Engineering 15: 165-170.

Hamby, D.M. 1994. A review of techniques for parameter sensitivity analysis of environmental models. Environmental Monitoring and Assessment 32 (2): 135-154.

Hampton, S., and M. Zafonte. 2002. Calculating compensatory restoration in natural resource damage assessments: recent experience in California. In Proceedings of 2002 California World Oceans Conference. CA: Santa Barbara.

Hartley, S. B., B. R. Couvillion, and N. M. Enwright. 2017. Delineation of Marsh Types and Marsh-type Change in Coastal Louisiana for 2007 and 2013: U.S. Geological Survey Scientific Investigations Report 2017-5044, 6 p., https://doi.org/10.3133/20175044.

Hester, M.W., J.M. Willis, S. Rouhani, M. Steinhoff, and M. Baker. 2016. Impacts of the deepwater horizon oil spill on the salt marsh vegetation of Louisiana. Environmental Pollution 216: 361-370.

Hoenig, J. 1983. Empirical use of longevity data to estimate mortality rates. Fishery Bulletin 81: 893-903.

Hollweg, T.A., M.C. Christman, J. Lipton, B.P. Wallace, M.T. Huisenga, D.R. Lane, and K.G. Benson. 2019. Meta-analysis of nekton recovery following marsh restoration in the northern Gulf of Mexico. Estuaries and Coasts. Special Section: Restoration Benefits in Gulf of Mexico. Published online October 30: 2019-2018. https:// doi.org/10.1007/s12237-019-00630-1.

Kemp, P.F., S.Y. Newell, and C.S. Hopkinson. 1990. Importance of grazing on the salt-marsh grass Spartina alterniflora to nitrogen turnover in a macrofaunal consumer, Littorina irrorata, and to decomposition of standing-dead Spartina. Marine Biology 104: 311-319.

Kesel, R. 1988. The decline in the suspended load of the lower Mississippi River and its influence on adjacent wetlands. Environmental Geology and Water Science 11: 271-281.

La Peyre, M.K., B. Gossman, and B.P. Piazza. 2009. Short-and long-term response of deteriorating brackish marshes and open-water ponds to sediment enhancement by thin-layer dredge disposal. Estuaries and Coasts 32: 390-402.

LaSalle, M.W., M.C. Landin, and J.G. Sims. 1991. Evaluation of the flora and fauna of a Spartina alterniflora marsh established on dredged material in Winyah Bay, South Carolina. Wetlands 11: 191-208.

Levrel, H., S. Pioch, and R. Spieler. 2012. Compensatory mitigation in marine ecosystems: which indicators for assessing the "no net loss" goal of ecosystem services and ecological functions? Marine Policy 36: $1202-1210$.

Lin, Q., and I.A. Mendelssohn. 2012. Impacts and recovery of the Deepwater horizon oil spill on vegetation structure and function of coastal salt marshes in the northern Gulf of Mexico. Environmental Science \& Technology 46 (7): 3737-3743.

Louisiana Coastal Wetlands Conservation and Restoration Task Force (LCWCRTF). 2014. Wetland Value Assessment Methodology: Coastal Community Marsh Model, Version 1.3. 78 pp. 
McTigue, T.A., and R.J. Zimmerman. 1998. The use of infauna by juvenile Penaeus aztecus (Ives) and Penaeus setiferus (Linnaeus). Estuaries 21: 160-175.

Michel, J., J. Hoff, K. Smith, M. Keiler, A. Rizzo, and R. Ayella. 2002. Injury to Wetlands Resulting from the Chalk Point Oil Spill. Report prepared for the Natural Resource Trustees by the Wetlands Assessment Team. https://casedocuments.darrp.noaa.gov/northeast/ chalk point/pdf/cpar2035.pdf

Minello, T.J., and R.J. Zimmerman. 1992. Utilization of natural and transplanted Texas salt marshes by fish and decapod crustaceans. Marine Ecology Progress Series 90: 273-285.

Moreno-Mateos, D., M.E. Power, F.A. Comin, and R. Yockteng. 2012. Structural and functional loss in restored wetland ecosystems. PLoS Biology 10 (1): e1001247. https://doi.org/10.1371/journal.pbio. 1001247.

National Oceanic and Atmospheric Administration (NOAA). 2006. Habitat equivalency analysis: an overview. NOAA Damage Assessment and Restoration Program. Policy and Technical Paper Series, Number 95-1. 24 pp.

National Oceanic and Atmospheric Administration (NOAA). 1999. Discounting and the treatment of uncertainty in natural resource damage assessment. Technical paper 99-1. NOAA Damage Assessment and Restoration Program. 43 pp.

Nixon, Z., S. Zengel, M. Baker, M. Steinhoff, G. Fricano, S. Rouhani, and J. Michel. 2016. Shoreline oiling from the deepwater horizon oil spill. Marine Pollution Bulletin 107 (1): 170-178.

Oceanic, National, and Atmospheric Administration (NOAA). 1996. 15 CFR part 990. Natural Resource Damage Assessments; Final Rule (January 5, 1996).

Peterson, C.H., and R.T. Kneib. 2003. Restoration scaling in the marine environment. Theme section. Marine Ecology Progress Series 264: 173-307.

Pianosi, F., K. Beven, J. Freer, J.W. Hall, J. Rougier, D.B. Stephenson, and T. Wagener. 2016. Sensitivity analysis of environmental models: A systematic review with practical workflow. Environmental Modelling \& Software 79: 214-232.

Powers, S.P. and S.B. Scyphers 2016. Estimating injury to nearshore fauna resulting from the Deepwater Horizon oil spill (NS_TR.17). DWH Shoreline NRDATechnical Working Group Report.

Sasser, C. E., J. M. Visser, E. Mouton, J. Linscombe, and S. B. Hartley. 2008. Vegetation Types in Coastal Louisiana in 2007: U.S. Geological Survey Open-File Report 2008-1224, 1 sheet, scale 1: 550,000 .

Sasser, C. E., J. M. Visser, E. Mouton, J. Linscombe, and S. B. Hartley, S.B. 2014. Vegetation Types in Coastal Louisiana in 2013: U.S. Geological Survey Scientific Investigations Map 3290, 1 sheet, scale 1:550,000. https://doi.org/10.3133/sim3290

Short, F.T., D.M. Burdick, C.A. Short, R.C. Davis, and P.A. Morgan. 2000. Developing success criteria for restored eel grass, salt marsh and mud flat habitats. Ecological Engineering 15: 239-252.
Silliman, B.R., and J.C. Zieman. 2001. Top-down control of Spartina alterniflora production by periwinkle grazing in a Virginia salt marsh. Ecology 82: 2830-2845.

Stagg, C.L., and I.A. Mendelssohn. 2010. Restoring ecological function to a submerged salt marsh. Restoration Ecology 18: 10-17.

Steyer, G.D., R.R. Twilley, and R.C. Raynie. 2006. An integrated monitoring approach using multiple reference sites to assess sustainable restoration in coastal Louisiana. In USDA Forest Service proceedings RMRS-P-42CD.

Strange, E., H. Galbraith, S. Bickel, D. Mills, D. Beltman, and J. Lipton. 2002. Determining ecological equivalence in service-to-service scaling of salt marsh restoration. Environmental Management 29 (2): 290-300.

Stratus Consulting and Toxicological \& Environmental Associates, Inc. 2006. Natural resource damages at the ExxonMobil Bayway and Bayonne sites. Prepared for state of New Jersey, Dept. of Environmental Protection. http://nynjbaykeeper.org/wp-content/ uploads/2015/04/Expert-Report-Lipton-Stratus-November-3-2006. pdf

Turner, R.E. 1997. Wetland loss in the northern Gulf of Mexico: multiple working hypotheses. Estuaries 20: 1-13.

Turner, R.E., and B. Streever. 2002. Approaches to coastal wetland restoration: Northern Gulf of Mexico. The Hague, Netherlands: SPB Academic Publishing.

U.S. Department of Justice (DOJ). 2015. Fact Sheet: Proposed Consent Decree with BP for the Deepwater Horizon/Macondo Well Oil Spill. https://www.justice.gov/enrd/file/780311/download.

U.S. Department of the Treasury. 2015. Services: Restore Act. https:// www.treasury.gov/services/restore-act/Pages/home.aspx .

U.S. Department of the Interior (U.S. DOI). 2008. 43 CFR Part 11. Natural resource damages from hazardous substances. Final Rule (2 October 2008)

Weinstein, M.P., J.M. Teal, J.H. Balletto, and K.A. Strait. 2001. Restoration principles emerging from one of the world's largest tidal marsh restoration projects. Wetlands Ecology and Management 9: $387-407$.

White, P.S., and J.L. Walker. 1997. Approximating nature's variation: selecting and using reference information in restoration ecology. Restoration Ecology 5: 338-349.

Zengel, S., N. Rutherford, B. Bernik, Z. Nixon, and J. Michel. 2014. Salt marsh remediation and the deepwater horizon oil spill, the role of planting in vegetation and macroinvertebrate recovery. International Oil Spill Conference Proceedings: May 20142014 (1): 1985-1999.

Zengel, S., C.L. Montague, S.C. Pennings, S.P. Powers, M. Steinhoff, G.F. Fricano, C. Schlemme, M. Zhang, J. Oehrig, Z. Nixon, S. Rouhani, and J. Michel. 2015. Impacts of the Deepwater horizon oil spill on salt marsh periwinkles (Littoraria irrorata). Environmental Science \& Technology 50: 643-652.

Zeug, S.C., V.R. Shervette, D.J. Hoeinghaus, and S.E.I. Davis. 2007. Nekton assemblage structure in natural and created marsh-edge habitats of the Guadalupe estuary, Texas, USA. Estuarine, Coastal and Shelf Science 71: 457-466. 